\title{
Perceptions and Use of English by Secondary School Students from Central Asia
}

\author{
Flora Komlósi \\ American University in Bulgaria \\ Correspondence concerning this article should be addressed to Flora Komlósi, American University in \\ Bulgaria, 1 Georgi Izmirliev Square, Blagoevgrad, Bulgaria, 2700. E-mail: flora.komlosi@yahoo.co.uk \\ Siarl Ferdinand \\ University of Wales Trinity Saint David \\ Correspondence concerning this article should be addressed to Siarl Ferdinand, University of Wales Trinity \\ Saint David, Lampeter Campus, Ceredigion, SA48 7ED. E-mail: yeth_kernewek@yahoo.co.uk
}

\begin{abstract}
After almost two centuries of functioning almost exclusively through the medium of Russian, the governments of the now-independent Kyrgyzstan are trying to implement the knowledge of English among the population as an auxiliary tool of interaction with the rest of the world. Nevertheless, and despite the huge amount of money invested in English education, there is a lack of studies about the attitudes of the Kyrgyzstani students toward this language and the use that they intend to do of it. This paper analyses the attitudes toward the learning and use of English by Kyrgyzstani secondary-school students from four educational models in two regions of the country. A questionnaire given to 182 students from different local and foreign ethnic and language backgrounds was used to collect data. The results of the research show different approaches depending on the location of the schools and the educational program followed. For most students English may be a good asset but very few consider it a language that can be used in contexts other than the classroom.
\end{abstract}

Keywords: Kyrgyzstan, language attitudes, L2 acquisition, multilingualism, motivation

Motivation plays an important role in the success of second and foreign language learning. It provides the starting impetus to initiate the process of learning another language and it is also the driving force to maintain the effort through the years, since it is responsible for determining human behavior by energizing it and giving it direction. Although there is not much agreement with regard to the exact meaning of the concept when related to scientific literature, it can be stated that etymologically, "to be motivated" or "to have motivation" means "to be moved to action toward something". Motivation is responsible for guiding human behavior by prompting and directing it and there is a great variety of theories and perspectives of how this happens. The reason for this range of opinions has its basis in the fact of human complexity since those psychological theories seek to explain why humans behave as they do; thus, it would be unreal to assume any simple and single answer. Therefore, basically every different psychological perspective on human behavior is associated with a different theory of motivation (Dörnyei \& Csizér, 1998, p. 117).

Motivation of learning a second language, in this case English, may differ depending on the country where the students come from and/or where the students learn the language. Therefore, Indian or Nigerian students, who have English as the interethnic official language in their respective countries, may regard English quite differently than Italians, for whom it is a useful international language, or than Quechuaspeaking students from rural Peru, for whom English is only a foreign language like French or Chinese, which can be learnt only after mastering Quechua and Spanish.

For centuries the only contact between Central Asia and the rest of the world was carried out through Russia and other Russian speaking regions. The Russian language became the only vehicle to establish any communication with the world including many of the neighboring nations while English was only a 
curiosity related to the enemy, who lived in far-away countries (Pavlenko, 2003, p. 313). The collapse of the USSR in the 1990s provoked deep changes in those societies. New states such as Kyrgyzstan emerged in a world where Russian was not the only language of culture. Since then, the Kyrgyz government has tried to implement the study and use of English by assigning it a compulsory amount of weekly hours in all the schools. Moreover, prosperity within certain sectors of the Kyrgyz society has provoked the establishment of schools through the medium of English. This paper seeks to analyze attitudes and motivations of secondary-school students in different regions Kyrgyzstan where English has traditionally played a minor role.

\section{Materials and Methods}

\section{Primary and Secondary Education in Kyrgyzstan}

Kyrgyzstan has an educational system structured according to the Soviet model which has been partially reformed after the independence in 1991. Official figures show 99.2 percent literacy with no significant gender, ethnic or regional differences. Nevertheless, the situation is far from being considered good. There is an overload of subjects and hours which, along with other factors such as teachers' lack of motivation, produces a continuous and long lasting falling in educational standards and quality (Naumann, 2011, pp. 24, 25; Hou, 2011, p. 1). An indicator of this failure can be perceived by the results of the PISA reports. According to the 2010 Report, Kyrgyzstan was the country which scored lowest in all areas, namely reading, science and mathematics, far below the other two ex-Soviet states monitored, Russia which has an average OECD education level, and Azerbaijan, also among the last countries of the list (see Table 1).

Table 1

Scores according to 2010 PISA report

\begin{tabular}{lclllll}
\hline \multicolumn{1}{c}{ Reading } & \multicolumn{2}{c}{$\begin{array}{c}\text { Reading } \\
\text { (position) }\end{array}$} & \multicolumn{2}{c}{$\begin{array}{c}\text { Science } \\
\text { (position) }\end{array}$} & \multicolumn{2}{c}{$\begin{array}{c}\text { Mathematics } \\
\text { (position) }\end{array}$} \\
\hline $\begin{array}{l}\text { First in World } \\
\text { Rank }\end{array}$ & $556 \begin{array}{c}\text { Korea } \\
(1)\end{array}$ & 563 & $\begin{array}{c}\text { Finland } \\
(1)\end{array}$ & 549 & $\begin{array}{c}\text { Taiwan } \\
(1)\end{array}$ \\
\hline $\begin{array}{l}\text { United } \\
\text { Kingdom }\end{array}$ & 469 & $(14)$ & 515 & $(12)$ & 495 & $(22)$ \\
\hline United States & - & $(-)$ & 489 & $(24)$ & 474 & $(32)$ \\
\hline $\begin{array}{l}\text { Russian } \\
\text { Federation }\end{array}$ & 440 & $(37)$ & 479 & $(33)$ & 476 & $(32)$ \\
\hline Azerbaijan & 353 & $(54)$ & 382 & $(55)$ & 476 & $(32)$ \\
\hline Kyrgyzstan & 285 & $(56-$ last) & 322 & $\begin{array}{l}(57 \\
- \text { last })\end{array}$ & 311 & $\begin{array}{l}(57 \\
- \text { last })\end{array}$ \\
\hline
\end{tabular}

(OECD, 2010, pp. 22, 47, 53)
There are 2191 schools in the Kyrgyz Republic, which also include 54 private schools. Although most schools offer Kyrgyz-only or bilingual KyrgyzRussian education, there are institutions which use other languages. The most important group is the 203 Russian-medium education schools distributed all over the country. Russian schools are highly prestigious and in high demand by not only Russian parents but also by those from other ethnic groups; in fact, about 60 percent of students in the Russian schools come from Kyrgyz speaking families (OECD, 2010, p. 175). This clear preference for Russian education can be easily explained by the much higher performance of the students ( 425 for Russian speaking students, 362 for Kyrgyz speaking students according to PISA 2006) when compared with their counterparts in Uzbek (307) and Kyrgyz schools (302). For them, it is also a good opportunity to be fully competent in the lingua franca of Central Asia, Russian (OECD, 2010, pp. 175, 183). There are 91 Uzbek-only schools and other 192 bilingual or multilingual schools where part of the education is in Uzbek. Due to the lack of funds, some of the schools are shutting their doors and many Uzbek parents send their children to study in Russianmedium schools. There are also a few part-time schools where Tajik is used as instruction language (Eurasianet, 2013). A number of private schools in the main cities offer education either through the medium of English-only or through the medium of English and any other language such as Russian.

Languages and literature play an important role in primary and secondary education in Kyrgyzstan, since between 33 and 50 percent of the time is devoted to subjects including Russian and Kyrgyz grammar and literature and foreign language learning, usually English or German (see Table 2). Despite this fact, Kyrgyzstan occupies the last position in the PISA ranking in reading in the local language(s) and only a maximum of 7 and 1 percent of its inhabitants declare to know English or German, respectively (OECD, 2006, pp. 47,53$)$.

\section{Methodological Issues and Considerations}

Prior to the actual carrying out of the study, the authors realized that although English is taught in almost every school of the country, the approach toward this foreign language varied considerably from one school to the other, depending on factors such as public or private funding, rural or urban location, national, minority or foreign curricula. It was decided, therefore, to include schools from all possible backgrounds.

\section{Participating Schools}

Four schools with different educational approaches 
Table 2

Language education in Kyrgyz medium schools in Kyrgyzstan

\begin{tabular}{lccccccccccc}
\hline & $\mathbf{1}^{\text {st }}$ & 2nd & 3rd & 4th & 5th & 6th & 7th & 8th & 9th & 10th & 11th \\
\hline Kyrgyz Language & 7 & 7 & 8 & 8 & 5 & 4 & 3 & $3 / 2$ & 2 & 2 & 2 \\
\hline Kyrgyz Literature & - & - & - & - & 3 & 3 & 3 & $2 / 3$ & 3 & 3 & 3 \\
\hline Russian Language & 3 & 4 & 4 & 4 & 2 & 2 & 2 & 1 & 1 & 2 & 2 \\
\hline Russian Literature & - & - & - & - & 2 & 2 & 2 & 2 & 2 & 2 & 2 \\
\hline Foreign Language & 2 & 2 & 2 & 2 & 4 & 3 & 2 & 2 & 2 & 2 & 2 \\
\hline
\end{tabular}

(OECD, 2010, p. 146-148)

and curricula were selected. Three of them are situated in the city of Bishkek and one in the province of JalalAbad. This selection was considered appropriate for the study as it basically includes representatives of all types of Kyrgyzstani students. The first school chosen is a National school in the city of Bishkek. It belongs to the main group of Kyrgyz schools, where students are supposed to study both national languages, Kyrgyz and Russian and a foreign language, English in this case. Students and teachers represent quite accurately the percental ethnic and linguistic composition of the city. There are a few hundred of schools where education is carried out in national languages which are not Kyrgyz. For this study an Uzbek school from the ethnically heterogeneous province of Jalal-Abad was selected. Education in this school follows the national curriculum of Kyrgyzstan except for the fact that students learn through the medium of their native language, Uzbek, while Kyrgyz and Russian are taught as subjects along with a foreign language, English. Since the object of this study is to observe the use of English among students, two private schools where English is used as a language of instruction were also selected. The first private school is a bilingual, or in fact a multilingual school, where education is offered through the medium of English and of the national languages, Russian and Kyrgyz. The second one is a small school which offers its services exclusively through the medium of English.

\section{Sampling: Participating Students}

A total of 182 students, 80 boys and 102 girls, from grades ninth to eleventh, the last in the Kyrgyz National Education System, took part in the survey (see Table 3). All participants were aged between 14 and 18. These ages were considered appropriate for the study of language attitudes since some scholars suggest that attitudes initially appear at the age of 10 and are clarified and consolidated during adolescence (Appel and Muysken, 1987; Siguan and Mackey, 1986 cited in Huget and Llurda, 2001, p. 271). Although most students belong to local ethnicities, there were some long-term resident and even Kyrgyzstan- born foreigners. The ethnolinguistic background of the participants varied according to the schools as specified in the following paragraphs and in Table 4.

Table 3

Distribution of participants by sex and school

\begin{tabular}{lccc}
\hline \multicolumn{1}{c}{ School } & Boys & Girls & Total \\
\hline (Uz) Minority-language (Uzbek) & 27 & 30 & 57 \\
\hline (KR) Kyrgyz-Russian national & 22 & 25 & 47 \\
\hline (EKR) Multilingual private & 18 & 29 & 47 \\
\hline (E) English-only private & 13 & 18 & 31 \\
\hline TOTAL & 80 & 102 & 182 \\
\hline
\end{tabular}

Table 4

Distribution of participants by sex and school

\begin{tabular}{lccc}
\hline \multicolumn{1}{c}{ School } & $\begin{array}{c}\text { Ethnic } \\
\text { Kyrgyz }\end{array}$ & $\begin{array}{c}\text { Other ex-USSR } \\
\text { nationals }\end{array}$ & Other \\
\hline $\begin{array}{l}\text { (Uz) Minority-language } \\
\text { (Uzbek) }\end{array}$ & $\begin{array}{c}53 \\
\text { (Uzbek) }\end{array}$ & 4 & - \\
\hline $\begin{array}{l}\text { (KR) Kyrgyz-Russian } \\
\text { national }\end{array}$ & 29 & 18 & - \\
\hline (EKR) Multilingual private & 20 & 5 & 22 \\
\hline (E) English-only private & 16 & 3 & 12 \\
\hline
\end{tabular}

*Ethnic Uzbeks for the minority language school

A total of 22 boys and 25 girls from a national Kyrgyz-Russian school (KR) accepted to participate in the survey. The ethnic background of the students in this school reflects the ethnic composition of Bishkek. Approximately 62 percent of them are ethnic Kyrgyz while the rest are mostly Russians (19 percent) and members of other ex-USSR nationalities such as Tatars, Volga Germans, Uzbeks or Uyghurs. As expected, most of the 27 boys and 30 girls of the minority language school (Uz) belong to the minority group, in this case Kyrgyzstani Uzbeks. In fact, only four students reported other nationalities, namely a Meskhetian Turk, a Russian and two Balkars from the Caucasus. A majority of the students in the multilingual school (EKR) are ethnic Kyrgyz. There are also representatives of some of the other local nationalities such as Uyghurs and Uzbeks. Russians and the rest of European minorities, 
however, are underrepresented. About half of the students are not from Kyrgyzstan although very few, if any, have English as their first language. This is due to the fact that the selected school was established by a Turkish organization; therefore, about 30 percent of the students are Kyrgyzstan-born children of longterm Turkish immigrants. The rest of the foreigners are usually children of Kyrgyz-Foreign mixed couples. Most Turkish and other foreign students are also fluent in Russian. Out of the 31 students who took part in the survey at the English monolingual school (E), 16 are ethnic Kyrgyz. The representative of the rest of the local nationalities is extremely reduced. The rest of the students are foreigners who mostly come from other Asian countries, especially Pakistan and Korea. Some of the foreigners are fluent Russian speakers, but a majority cannot generally interact in other language but English.

\section{The Instrument: The Questionnaire}

The instrument used in this studywas a questionnaire designed by the authors (see Appendix). It was written in English but since not all the participants had enough skills to fully understand the questions in that language, a Russian version was also produced. The document handed out to the participants contained a bilingual English-Russian copy of the questionnaire. These languages were preferred over Kyrgyz or any other local language since all the students were fluent in at least one of them. Moreover, since the survey was addressed to a highly intermixed multicultural population, it would have been unrealistic to prepare translations in the languages of the tens of minorities of the country, including not only Kyrgyz, Uzbek and Russian but also Tatar, Dungan, Tajik, Turkish, Korean as well as many others, plus an indefinite number of foreign languages spoken by the foreign students. To enhance success, students were allowed to answer in their native language, no matter what it is. The answers received were written in Russian, Uzbek, Kyrgyz and English.

The results are based on a five-point Likert scale questionnaire (from ' 1 ' strongly disagree to ' 5 ' strongly agree). Every school was codified into two main categories: boys and girls. A column for general results by school was also produced. This division is important since often attitudes toward languages may differ considerably according to gender (Fishman, 1991, p. 184).

The survey was implemented during the months of May and June 2015 after obtaining the permission from administrations of the four schools. It was handed out by local teachers who could give instructions to their students in their native languages about how to fill the questionnaire.

\section{Results}

The following analysis is based on the answers of local students from Kyrgyzstan as well as some foreign students from other Central Asian Russianspeaking countries since both groups may have similar attitudes toward English, a foreign language. Non-Russian foreign students were not considered for this study for two main reasons. Foreign students are but a tiny minority in the schools in Kyrgyzstan, therefore their attitudes cannot be representative of the attitude of Central Asians toward English. Moreover, the viewpoint that Europeans, Americans, Hindustanis and other students for whom English is a living language that is also used as a tool to live in foreign countries like Kyrgyzstan, may be totally different from the Kyrgyz, Uzbek or Central Asian Russian perspective, for whom English is a foreign language with not much value in local life.

\section{Use of English Within the Family Circle}

In a country where for most people English is only a foreign language spoken far-away, the use of that foreign language within the family circle among the students of Kyrgyzstan is directly related to two main factors: the location of the school and the exposition to English during education, the latter being the most influential.

Bishkek is the only rather cosmopolitan center in Kyrgyzstan. For this reason, it is not surprising that the school situated in Jalal-Abad (Uz) reported no student at all using any English with their siblings, despite being one of the languages studied by all the students. Moreover, apparently none of their parents is fluent in English, therefore it cannot be used as a common language at home. The school focus is on the use of Uzbek as a daily language. Nevertheless, most students' families are also very interested in the learning of Russian since, according to some members of the Uzbek community, the Russian language can provide more opportunities to children than any other language (Eurasianet, 2013). Many families are also trying to migrate to Russia, where there are already more than 2 million Uzbeks (Sadykov, 2014). The third language studied is Kyrgyz, as the school is situated in Kyrgyzstan. Although this language is not generally appreciated by the Uzbek minority, it must be used in commerce, in official documents and in daily life when contacting local ethnic Kyrgyz. Kyrgyz is, therefore, a living language for the Uzbek minority. English is the only foreign language in the Uzbek school curriculum. There are not many opportunities to speak it in JalalAbad and, in fact, it is not necessary in any concrete field. The rest of the schools are situated in the capital 
city. In all of them, there are a few local and foreign families who use English in their daily life and even some students employ it to talk to their siblings, in most cases as an auxiliary language rather than as a real communication tool.

In the national school (KR) 6 percent of the fathers and 15 percent of mothers are reported to be fluent in English. Some of them have been living abroad, where they learnt the language but some others have learnt it in Kyrgyzstan due to reasons related to their jobs in a big city. Some students reported parents who are able to hold conversations in Chinese and other foreign languages as well. In spite of these favorable conditions, English is not used by any family in their private conversations. The number of students who use English as an auxiliary language is still residual since only a maximum of 2 percent of them would do it. Once again the reason for this lack of use of English must be attributed to the attraction toward Russian as an international language. In fact, most students from all ethnical backgrounds reported Russian as the common family language instead of Kyrgyz or any other language.

The situation in the two private schools where some or all subjects are taught through the medium of English differs in many senses from that of the two previous schools. In the multilingual school (EKR), about half of the students are foreign nationals. Most of them are Turkish, therefore the rate of families that use English in their daily life is as low as that of local families from Kyrgyzstan. However, there is a notable increase among the students who use English as an auxiliary language to talk to their siblings. In fact, about 1 in 3 students communicate in English along with other languages such as Russian, Kyrgyz and Turkish.

The most important rate of use of English was observed in families and students from the English monolingual school (E). This increment applies to both, those with Russian as first or second language, and foreigners from non-Russian speaking countries. One of the reasons that may explain the use of English within the foreign families may be found in their countries of origin. A significant percentage of the foreign students come from India and Pakistan where English is employed on a daily base in all domains. Therefore, these families continue their life in English and other languages as they did in their home countries. It has also been observed that some of the local students come from mixed Kyrgyz/foreign families and from families that have lived abroad. This multicultural background helps parents and children maintain English as one of the common languages spoken at home. Education also plays a very important role in the use of the foreign language since about 42 percent of all the students (in identical rates in both, Russian-speaking students and foreign students) use
English, mainly as an auxiliary language, to talk to their siblings. Nevertheless, there is a final reason that must not be forgotten. Most students who attend the English-only school come from wealthy families with possibilities to visit countries where English is spoken. Very often, these students consider English the language to talk to foreign friends and acquaintances while on holidays, creating in them a positive feeling of usefulness.

\section{Use of English in Spare Time}

English is not currently spoken in Kyrgyzstan. Due to this fact, all the questions related to the use of English during the students' spare time had to be designed taking into account the rather scarce opportunities that average Kyrgyzstan inhabitants have to speak and/or listen to material in English. These items deal with three specific fields, travelling abroad, music, and activities related to the Internet such as reading websites, watching videos or films in English, etc. They are formulated from two perspectives, students' current attitudes toward English ('Do you like...?') and their motivation to develop skills ('I want to...').

The first discernible detail is the marked difference between the answers of the rural school (Uz) and the schools situated in the capital city. In all five items related to this topic (Questions 2:4 'Do you like watching TV, films or videos in English?'; 2:5 'Do you like listening to music in English?'; 3:1 'Knowing English will help me when travelling abroad on holidays'; $4: 8$ 'I want to understand better English films, videos, $T V$ ' and 4:9 'I want to be able to read websites in English', the school (Uz) in Jalal-Abad province scored much lower than the other schools (see Table 5). Nevertheless, it does not imply uniformity by the three schools of Bishkek since answers by the students also show some differences mainly provoked by the educational model followed by each center. The only generalized positive answer is to the item 'Knowing English will help me when travelling abroad on holidays' (Question 3:1), since the overwhelming majority of students of all the schools 'agree' or 'strongly agree' with the statement.

Students' attitudes toward English in music, films and videos as reported in answers to questions 2:4 and 2:5 are rather neutral in Jalal-Abad (both under 4 points). Both bilingual schools, (KR) and (EKR), have similar behaviors, good disposition toward music but a colder approach toward videos and cinema. The reason for this behavior may be supported by the fact that language is not necessary to enjoy music, therefore students may like to listen to songs in languages that they cannot understand as long as the rhythm and the melody are pleasant. However, understanding dialogues in films and videos is vital to enjoy them. Understanding requires a higher competence in the target language, English in this case, which many 
students do not possess. The monolingual English school (E), probably due to the higher command of English that most students exhibit, have positive attitudes to both issues, always scoring over 4 points (Agree).

As for their motivation to improve their skills, the rural school showed even less interest in contrast with urban students, particularly girls from all three schools who would agree to do something in order to understand much better material written or spoken in English. Interestingly, the group with less motivation is that of the boys from the multilingual school (EKR) while the more motivated are the girls from the same school. In general, rural students have an apathetic attitude toward English

Table 5

Use of English in spare time by schools excluding nonRussian speaking students

\begin{tabular}{|c|c|c|c|}
\hline $\begin{array}{c}\text { (Uz) Uzbek } \\
\text { school }\end{array}$ & $\begin{array}{l}\text { (KR) Kyrgyz- } \\
\text { Russian sch. }\end{array}$ & $\begin{array}{l}\text { (EKR) Multi- } \\
\text { lingual sch. }\end{array}$ & $\begin{array}{l}\text { (E) English } \\
\text { sch. }\end{array}$ \\
\hline $\begin{array}{l}\text { Boys - Girls } \\
\text { - Total }\end{array}$ & $\begin{array}{l}\text { Boys - Girls } \\
\text { - Total }\end{array}$ & $\begin{array}{l}\text { Boys - Girls } \\
\text { - Total }\end{array}$ & $\begin{array}{l}\text { Boys - Girls } \\
\text { - Total }\end{array}$ \\
\hline \multicolumn{4}{|c|}{ 2:4/Do you like watching TV, films or videos in English? } \\
\hline $3.85-3.62$ & $357-370$ & $325-400$ & $4.13-4.67$ \\
\hline-3.73 & -3.63 & -3.77 & -4. \\
\hline \multicolumn{4}{|c|}{ 2:5/ Do you like listening to music in English? } \\
\hline $3.44-3.70-3.57$ & $\begin{array}{l}4.40-4.74 \\
-4.57\end{array}$ & $\begin{array}{l}4.25-4.81 \\
-4.62\end{array}$ & $\begin{array}{l}4.63-4.83 \\
\quad-4.75\end{array}$ \\
\hline \multicolumn{4}{|c|}{$\begin{array}{l}\text { 3:1/ Knowing English will help me when travelling abroad on } \\
\text { holidays }\end{array}$} \\
\hline $4.46-4.12-4.29$ & $\begin{array}{l}4.90-4.88 \\
\quad-4.89\end{array}$ & $\begin{array}{l}4.88-4.88 \\
-4.88\end{array}$ & $\begin{array}{l}4.75-4.83 \\
\quad-4.80\end{array}$ \\
\hline \multicolumn{4}{|c|}{ 4:8/ I want to understand better English films, videos, TV } \\
\hline $3.04-3.17-3.10$ & $\begin{array}{l}3.95-4.29 \\
-4.12 \\
\end{array}$ & $3.88-4.47-4.28$ & $\begin{array}{c}4.25-4.42 \\
-4.35 \\
\end{array}$ \\
\hline \multicolumn{4}{|c|}{ 4:9/ I want to be able to read websites in English } \\
\hline $3.42-3.31-3.36$ & $\begin{array}{l}4.00-3.95 \\
-3.98\end{array}$ & $\begin{array}{l}3.88-4.35 \\
-4.20\end{array}$ & $\begin{array}{l}4.00-4.42 \\
-4.25\end{array}$ \\
\hline
\end{tabular}

\section{Use of English Regarding Studies}

Although the students from Bishkek are more positive toward the idea of using English outside the classrooms than those in Jalal-Abad (Question 2:8), the disposition toward that practice is still very mild. Not even in the monolingual English school (E) the average answer reaches the 4-point 'Agree' level (see Table 6). This fact could imply that English is only learnt to pass exams; however, when asked directly whether that is their main reason to study it (Question 3:5), most students answered negatively. Only the students of the Uzbek school (Uz) of Jalal-Abad gave neutral answers ( 3 points), most probably because for most of them English is only a school subject which is not appreciated in general.

The idea of having good competence in English as a tool to have the possibility to study abroad is shared by most students (Question 3:2). Once again, the mildest are those from Jalal-Abad who only score 3.75. The more English is used in education, the more positive the answer is, from 4.04 in the national school (KR) and 4.56 in the multilingual school (EKR) to a strong 4.75 in the English school (E). It is also a fact that about 50 percent of the students who graduated from the multilingual school (EKR) have attended foreign universities and colleges, mostly in Turkey, which is promoted by the school administration as one of the ultimate goals.

The use of English for studying at university in Kyrgyzstan seems to be directly related to the possibility to study abroad (Question 3:4). Thus, according to the answers of the students from the English school (E) and the boys from the multilingual school (EKR), that is to say, those who have the possibility to complete their education abroad, English is not necessary to study at a Kyrgyzstani university. The girls of the multilingual school (EKR) do not discard that they may have to study in their country and that English would be an excellent asset. This notable difference between boys and girls in the same school may indicate either actual discrimination within a considerable number of families toward promoting girls education, or a subconscious reflection of this traditional practice in Kyrgyzstan (Naumann, 2011, p. 25). Nevertheless, it must be noticed that the described tendency has not been particularly observed within the urban families of the national Kyrgyz-Russian school (KR) or within the wealthier families of the English school (E).

Table 6

Use of English in relation to education by schools excluding non-Russian speaking students

\begin{tabular}{cccc}
\hline $\begin{array}{c}\text { (Uz) Uzbek } \\
\text { school }\end{array}$ & $\begin{array}{c}\text { (KR) Kyrgyz- } \\
\text { Russian sch. }\end{array}$ & $\begin{array}{c}\text { (EKR) Multi- } \\
\text { lingual sch. }\end{array}$ & $\begin{array}{c}\text { (E) English } \\
\text { sch. }\end{array}$ \\
\hline $\begin{array}{c}\text { Boys - Girls } \\
\text { - Total }\end{array}$ & $\begin{array}{c}\text { Boys - Girls } \\
\text { - Total }\end{array}$ & $\begin{array}{c}\text { Boys - Girls } \\
\text { - Total }\end{array}$ & $\begin{array}{c}\text { Boys - Girls } \\
\text { - Total }\end{array}$ \\
\hline \multicolumn{4}{c}{ 2:8/ We should use English out of the classroom too } \\
\hline $2.84-3.46$ & $3.67-3.62$ & $3.00-3.88$ & $3.75-3.66$ \\
-3.16 & -3.64 & -3.60 & -3.70 \\
\hline \multicolumn{5}{c}{ 3:2/ I want to learn English to study abroad } \\
\hline $3.73-3.78$ & $4.24-3.83$ & $4.60-4.56$ & $4.60-4.83$ \\
-3.75 & -4.04 & -4.60 & -4.75 \\
\hline
\end{tabular}

3:4/ I want to learn English because I will need it at University in my country

\begin{tabular}{|c|c|c|c|}
\hline $\begin{array}{c}3.04-3.32 \\
-3.18\end{array}$ & $\begin{array}{c}3.85-3.88 \\
-3.87\end{array}$ & $\begin{array}{c}2.75-4.41 \\
\quad-3.88\end{array}$ & $\begin{array}{c}2.62-2.33 \\
-2.45\end{array}$ \\
\hline \multicolumn{4}{|c|}{ 3:5/ The main reason to learn English is to pass exams } \\
\hline $\begin{array}{c}3.23-2.86 \\
-3.04\end{array}$ & $\begin{array}{c}2.76-2.13 \\
-2.44\end{array}$ & $\begin{array}{c}1.85-2.94 \\
-2.63\end{array}$ & $\begin{array}{c}2.88-2.33 \\
-2.55\end{array}$ \\
\hline \multicolumn{4}{|c|}{ 4:9/ I want to be able to read websites in English } \\
\hline $\begin{array}{c}3.42-3.31 \\
-3.36\end{array}$ & $\begin{array}{c}4.00-3.95 \\
-3.98\end{array}$ & $\begin{array}{c}3.88-4.35 \\
-4.20\end{array}$ & $\begin{array}{c}4.00-4.42 \\
-4.25\end{array}$ \\
\hline
\end{tabular}




\section{Discussion and Conclusion}

\section{Intention to Use English in the Future}

The set of questions related to the use of English in the students' future lives included aspects such as their willingness to transmit English to the next generation (Question 2:10), their projects to use English in a country where it is actually spoken as a community language (Question 3:3) and their trust in English as a tool to have a good life (Question 3:10). The results are shown in detail in Table 7 . The transmission of English to the next generation does not seem to be an issue for the rural students $(\mathrm{Uz})$ since while most girls remain neutral to that option, many of the boys are directly opposed. Curiously, a similar behavior is observed among the boys of the multilingual school (EKR). All the rest of the groups agree to teach English to their children, the girls of all schools being more enthusiastic about it. The motivation to learn English in order to spend some time in an English-speaking country does not receive the support of the students of Kyrgyzstan in general. Only the students of the multilingual school (EKR) and the boys of the English school (E) agree with that item while the rest of the groups show a rather cold attitude. The answers to Question 3:10 show that although English is often considered an asset, students do not have faith in it as the key to have a better life.

Table 7

Use of English in the student's prospective future life by schools excluding non-Russian speaking students

\begin{tabular}{|c|c|c|c|}
\hline $\begin{array}{l}\text { (Uz) Uzbek } \\
\text { school }\end{array}$ & $\begin{array}{l}\text { (KR) Kyrgyz- } \\
\text { Russian sch. }\end{array}$ & $\begin{array}{l}\text { (EKR) Multi- } \\
\text { lingual sch. }\end{array}$ & $\begin{array}{l}\text { (E) English } \\
\text { sch. }\end{array}$ \\
\hline $\begin{array}{l}\text { Boys - Girls } \\
\text { - Total }\end{array}$ & $\begin{array}{l}\text { Boys - Girls } \\
\text { - Total }\end{array}$ & $\begin{array}{l}\text { Boys - Girls } \\
\text { - Total }\end{array}$ & $\begin{array}{l}\text { Boys - Girls } \\
\text { - Total }\end{array}$ \\
\hline \multicolumn{4}{|c|}{ 2:10/ When I have a child I will teach him/her English } \\
\hline $2.85-3.40-3.14$ & $\begin{array}{l}4.10-4.29 \\
\quad-4.19\end{array}$ & $\begin{array}{l}3.75-4.41 \\
\quad-4.20\end{array}$ & $\begin{array}{l}4.13-4.75 \\
\quad-4.50\end{array}$ \\
\hline \multicolumn{4}{|c|}{$\begin{array}{l}\text { 3:2/ I am learning English because I want to spend some time in an } \\
\text { English-speaking country }\end{array}$} \\
\hline $3.56-3.41-3.48$ & $\begin{array}{l}3.95-3.75 \\
-3.85\end{array}$ & $\begin{array}{l}4.50-4.47 \\
-4.48\end{array}$ & $\begin{array}{c}4.38-3.66 \\
-3.95\end{array}$ \\
\hline \multicolumn{4}{|c|}{ 3:10/ If I speak English, I will have a fantastic life } \\
\hline $2.23-2.44-2.33$ & $\begin{array}{c}3.45-2.75 \\
\quad-3.10\end{array}$ & $\begin{array}{c}2.13-2.94 \\
-2.68\end{array}$ & $\begin{array}{c}2.38-2.33 \\
-2.35\end{array}$ \\
\hline
\end{tabular}

\section{Use of English Related to Future Job's Opportunities and Money}

English is perceived by most urban students as an asset in their future careers (see Table 8). In fact, all groups except the boys of the multilingual school (EKR) agree with the item 3:6 'If I learn English, I will be able to get a better job'. As for the Uzbek students of the rural school (Uz), they have a neutral view on the issue. This privileged position that English can offer the urban students is not considered as a key to economic or social advantages by any of the groups, according to the answers to two questions $3: 8$ and 3:7. To item 3:8 'If I speak English, I will earn more money' all the groups gave a neutral answer between 3.00 (Uzbek school (Uz) boys) and 3.90 (national school (KR) boys). Question 3:7 deals with the issue relating knowledge of English to acquisition of better category in the workplace such as the generic 'boss'. Again, most students gave apathetic answers and even some groups such as the Uzbek boys (Uz), the girls of the national school (KR) and the girls of the English school (E) answered negatively to the item (between 2.83 and 2.93). Due to these answers, it can be deduced that the possible advantages that English can offer are limited to the choice of a more pleasant job rather than a more remunerated employment. That perspective of choosing instead of accepting any job to make a life seems attractive enough in the capital city to help students pursue in their study of English.

Table 8

Use of English regarding future job opportunities by schools excluding non-Russian speaking students

\begin{tabular}{|c|c|c|c|}
\hline $\begin{array}{l}\text { (Uz) Uzbek } \\
\text { school }\end{array}$ & $\begin{array}{l}\text { (KR) Kyrgyz- } \\
\text { Russian sch. }\end{array}$ & $\begin{array}{l}\text { (EKR) Multi- } \\
\text { lingual sch. }\end{array}$ & $\begin{array}{l}\text { (E) English } \\
\text { sch. }\end{array}$ \\
\hline $\begin{array}{c}\text { Boys - Girls } \\
\text { - Total }\end{array}$ & $\begin{array}{c}\text { Boys - Girls } \\
\text { - Total }\end{array}$ & $\begin{array}{c}\text { Boys - Girls } \\
\text { - Total }\end{array}$ & $\begin{array}{c}\text { Boys - Girls } \\
\text { - Total }\end{array}$ \\
\hline \multicolumn{4}{|c|}{ 3:6/ If I learn English, I will be able to get a better job } \\
\hline $3.44-3.59-3.51$ & $\begin{array}{c}4.33-4.39 \\
-4.36\end{array}$ & $\begin{array}{c}3.86-4.47 \\
-4.25\end{array}$ & $\begin{array}{c}4.13-4.17 \\
-4.15\end{array}$ \\
\hline \multicolumn{4}{|c|}{ 3:7/ If I learn English, I will be a boss in my job } \\
\hline $2.93-3.50-3.21$ & $\begin{array}{c}3.52-2.91 \\
-3.22\end{array}$ & $\begin{array}{c}3.00-3.53 \\
-3.36\end{array}$ & $\begin{array}{c}3.38-2.83 \\
-3.05\end{array}$ \\
\hline \multicolumn{4}{|c|}{ 3:8/ If speak English, I will earn more money } \\
\hline $3.00-3.67-3.33$ & $\begin{array}{c}3.90-3.42 \\
-3.66\end{array}$ & $\begin{array}{c}3.75-3.59 \\
-3.64\end{array}$ & $\begin{array}{c}3.50-3.33 \\
-3.40\end{array}$ \\
\hline
\end{tabular}

\section{Use of English in Other Personal Domains}

Popularity is a concept promoted in many films and TV soaps made mainly in the United States. A similar idea, that of leadership, is also promoted in many modern schools, with a special emphasis in international schools and in schools where education is carried out through the medium of English in countries where English is not a native language. The idea relating English to those concepts, however, does not seem to have permeated into the students' minds. Question 3:9 'If I speak English, I will be more popular' not only received the usual neutral answers from the rural students (Uz) and in this case from the boys of the national school (KR) as well, but also negative answers from all the rest of the groups without exception. Similar answers were given to the item 4:11 'When 
I speak English I feel superior to others'. The answers to these questions reinforce the idea that English, although practical in some domains, does not produce any superiority over those who speak Kyrgyz, Russian or any of the other local language (see Table 9).

Table 9

Use of English in other personal domains by schools excluding non-Russian speaking students

\begin{tabular}{|c|c|c|c|}
\hline $\begin{array}{c}\text { (Uz) Uzbek } \\
\text { school }\end{array}$ & $\begin{array}{l}\text { (KR) Kyrgyz- } \\
\text { Russian sch. }\end{array}$ & $\begin{array}{l}\text { (EKR) Multi- } \\
\text { lingual sch. }\end{array}$ & $\begin{array}{l}\text { (E) English } \\
\text { sch. }\end{array}$ \\
\hline $\begin{array}{c}\text { Boys - Girls } \\
\text { - Total } \\
\end{array}$ & $\begin{array}{c}\text { Boys - Girls } \\
\text { - Total } \\
\end{array}$ & $\begin{array}{c}\text { Boys - Girls } \\
\text { - Total } \\
\end{array}$ & $\begin{array}{c}\text { Boys - Girls } \\
\text { - Total } \\
\end{array}$ \\
\hline \multicolumn{4}{|c|}{ 3:9/ If I speak English, I will be more popular } \\
\hline $3.16-3.22-3.19$ & $\begin{array}{c}3.40-2.62 \\
-3.01\end{array}$ & $\begin{array}{c}2.25-2.76 \\
-2.60\end{array}$ & $\begin{array}{c}2.63-2.42 \\
-2.50\end{array}$ \\
\hline \multicolumn{4}{|c|}{ 4:11/ When I speak English I feel superior to others } \\
\hline $2.72-2.85-2.78$ & $\begin{array}{c}3.35-3.00 \\
\quad-3.17\end{array}$ & $\begin{array}{c}3.13-3.47 \\
-3.36\end{array}$ & $\begin{array}{c}3.00-2.58 \\
-2.75\end{array}$ \\
\hline
\end{tabular}

In this study, the different attitudes toward English of Kyrgyzstani and other Central Asian students of different ethnicities are described and some data may contribute to a better knowledge of what those students expect of foreign languages and how they intend (if there is any intention) to use them in their lives. First, it must be emphasized that students have in general a positive attitude toward the learning of foreign languages, in this case English. That approach, however, varies considerably depending on the location of the schools and the programs implemented. Rural students, for example, are in general skeptic to assign any real life value to English. For them that language is a school subject that might open some possibilities as well as mathematics or sciences do. None of them report to use English at home; very few show interest in entertainment products in English and a considerable percentage of them deny that knowing English may contribute to have a better life. The reason behind this apathy may be the lack of opportunities to use a foreign language in rural Kyrgyzstan. Moreover, for most Uzbeks, as well as for most inhabitants of Central Asia, the language that needs to be mastered is Russian, since it may be used as a tool to migrate to the Russian Federation, where economic conditions are far better than in Kyrgyzstan despite the economic crisis (Luhn, 2015; Eurasianet, 2013). Urban students show similar attitudes toward English among them, although it is also noticeable that the more English is used in the classroom the more positive the approach toward the language is expressed. For most students in the national schools (which account for most of the schools in the country) English may be an asset but very few use it in their daily lives. For most Kyrgyz families Russian is still the language to learn and to speak. Britta Korth (2005, p.
132) points to this fact when commenting that Russian schools are overcrowded and work in two or more shifts. The situation is different within the private English and multilingual schools (no more than 30 in all the country). Some of the students use English to talk to their siblings, although very often that use is very limited due to the insufficient competence in the language observed by the researchers. Contrarily to what happens in other towns, the cosmopolitan environment of the conurbation Bishkek-Almaty helps students of all schools consider English a useful language, one of the assets to accede to more pleasant jobs. Students are also happy to consume music, films and internet resources in English although many of them express rather weak desires to improve the skills that they have achieved so far. Despite these positive results, the attitude of the students toward a language like English is far from that noticed in other regions such as the European Union where 67 percent of the people think that English is the most useful language for personal development (European Commission, 2012, p. 69). This tendency, however, is likely to change as Kyrgyzstan continues its integration in international organizations and its visibility by other countries increases, attracting more tourism and investment.

\section{References}

Abazov, R. (2004). Historical dictionary of Kyrgyzstan. Oxford, UK: The Scarecrow Press.

Aminov, K., Jensen, V., Juraev, S., Overland, I., Tyan, D., \& Uulu, Y. (2010). Language use and language policy in Central Asia. Central Asia Regional Data Review, 1(2), 1-29.

Chotaeva, Ch. (2004). Language as a nation building factor in Kyrgyzstan. Central Asia and the Caucasus, 2(26), 177-184.

Comrie, B. (1981). The languages of the Soviet Union. Cambridge, UK: Cambridge University Press.

Crystal, D. (2000). Language death. Cambridge, UK: Cambridge University Press.

Dörnyei, Z., \& Csizér, K. (1998). Ten commandments for motivating language learners: Results of an empirical study. Language Teaching Research, 2, 203-229.

Eurasianet. (2011, February 17). Kyrgyzstan: Driving the Russian language from public life. Retrieved from http://www.eurasianet.org/node/62916

Eurasianet. (2013, March 6). Kyrgyzstan: UzbekLanguage schools disappearing. Retrieved from http://www.eurasianet.org/node/66647

European Commission. (2012). Special Eurobarometer 386. Europeans and their languages. Retrieved from 
http://ec.europa.eu/public_opinion/index_en.htm

Farooq, U. (2015, April 24). Hope and fear: Kyrgyz migrants in Russia. IRIN. Retrieved from http:// www.irinnews.org/report/101398/hope-and-fearkyrgyz-migrants-in-russia

Fishman, J. A. (1991). Reversing language shift: Theoretical and empirical foundations of assistance to threatened languages. Clevedon, UK: Multilingual Matters.

Grenoble, L. A. (2003). Language policy in the Soviet Union. New York, NY: Kluwer Academic Publishers.

Huguet, À. \& Llurda, E. (2001). Language attitudes of school children in two Catalan/Spanish bilingual communities. International Journal of Bilingual Education and Bilingualism, 4(4), 267-282.

Hou, D. (2011). Education reform in the Kyrgyz Republic. Knowledge Brief, 40.

International Republican Institute. (2012, February). Survey of Kyrgyzstan public opinion. Retrieved from http://www.iri.org/sites/default/files/2012\%20 April\%2011\%20Survey\%20of\%20Kyrgyzstan\%20 Public\%200pinion,\%20February\%204-27,\%20 2012.pdf

Korth, B. (2005). Language attitudes toward Kyrgyz and Russian. Discourse, education and policy in PostSoviet Kyrgyzstan. Bern, Switzerland: Peter Lang.

Landau, J. M., \& Kellner-Heinkele, B. (2012). Language politics in contemporary Central Asia. London, UK: I. B. Tauris.

Luhn, A. (2015, June 8). Why are migrants fleeing Moscow? The Guardian. Retrieved from http:// www.theguardian.com/cities/2015/jun/08/whymigrants-fleeing-moscow-permits-economy

National Statistical Committee of the Kyrgyz Republic.
(2009). Population and housing census of the Kyrgyz Republic of 2009. Bishkek, Kyrgyz Republic: NSCKR. Naumann, M. (2011). Situation assessment of children in the Kyrgyz Republic. Bishkek, Kyrgyz Republic: UNICEF.

O'Callaghan, L. (2004-5). War of words. Language policy in post-independence Kazakhstan. Nebula, 1(3), 197-216.

Odagiri, N. (2012). A study on language competence and use by ethnic Kyrgyz people in post-Soviet Kyrgyzstan: Results from interviews. Inter-Faculty, $3,1-24$.

OECD. (2007). PISA 2006: Science competencies for tomorrow's world executive summary. OECD Publishing. Retrieved from http://www.oecd.org/ pisa/pisaproducts/39725224.pdf

OECD. (2010). Kyrgyz Republic 2010: Lessons from PISA. OECD Publishing. Retrieved from http:// dx.doi.org/10.1787/9789264088757-en

Pavlenko, A. (2003). Languages of the enemy: Foreign language education and national identity. International Journal of Bilingual Education and Bilingualism, 6(5), 313-331.

Results of an empirical study. Language Teaching Research, 2, 203-229.

Sadykov, M. (2014, July 9). Uzbekistan: Minorities taking advantage of new Russian citizenship rules. Retrieved from http://www.eurasianet.org/node/68936

UNESCO. (2010). World data on education VII Ed. 2010/11 - Kyrgyz Republic. Retrieved from http:// www.ibe.unesco.org/fileadmin/user_upload/ Publications/WDE/2010/pdf-versions/Kyrgyzstan. pdf 


\section{Appendix \\ Questionnaire (English version)}

PART 1

Nationality (according to your passport):

Ethnicity (such as Dungan, Uyghur, Kurdish, etc.):

Common language spoken at home (Name the

language or languages):

My mother's family (grandparents, uncles, aunties) speak (Name the language or languages):

My mother speaks fluently (Name the language or languages):

My father's family (grandparents, uncles, aunties) speak (Name the language or languages):

My father speaks fluently (Name the language or languages):

My father talks to my mother in (Name the language or languages):

With my brothers and sisters I speak (Name the language or languages):

\section{PART 2}

4/Do you like watching TV, films or videos in English?

5/ Do you like listening to music in English?

2:8/ We should use English out of the classroom too

2:10/ When I have a child I will teach him/her English
PART 3

1/ Knowing English will help me when travelling abroad on holidays

3:2/ I want to learn English to study abroad

3:3/ I am learning English because I want to spend some time in an English-speaking country

3:4/ I want to learn English because I will need it at University in my country

3:5/ The main reason to learn English is to pass exams

3:6/ If I learn English, I will be able to get a better job

3:7/ If I learn English, I will be a boss in my job

3:8/ If speak English, I will earn more money

3:9/ If I speak English, I will be more popular

3:10/ If I speak English, I will have a fantastic life

\section{PART 4}

4:8/ I want to understand better English films, videos, TV

4:9/ I want to be able to read websites in English

$4: 11 /$ When I speak English I feel superior to others 